\title{
The Taxonomical Observations on the Natural Variation in Lilium speciosum Thunb. II*
}

\author{
By Sadao ABE and Teruo TAMURA**
}

阿部定夫・田村輝夫:** カノコュリの自然変異と分類学的考察 II*

Received September 22, 1955.

(Continued)

\section{Classification and Description}

The description of the varieties and forms of $L$. speciosum has been made since Siebold and Zuccarini (1838). They were followed by Masters (1872), Baker (1873), Elwes (1880), Tilton (1916), Wilson (1925), Woodcock and Coutts (1935), Woodcock and Stearn (1949) and others. They arranged them for 7 to 10 varieties and forms. The majority of variants were regarded as forms, while Baker or Woodcock and Stearn considered them as ranks of varieties, and Wilson arranged them for both varieties and forms. The descriptions and classifications have been given almost only in Europe, and the bulbs imported from Japan and their clones have been the subjects of them. In Japan no such studies have been made excepting those by Hayata $(1911,1912)$, in which our Formosa-type was named as $L$. Konishii and $L$. Kanahirai. Wilson (1925) untied Hayata's two species and put them into var. gloriosoides Baker of Central Chinese origin, which was regarded as a geographical race of $L$. speciosum by him. A plate of $L$. speciosum var. gloriosoides by Watson (1931) can be determined to be the Formosa-type. The Japanese geographical races of this lily found by us differ distinctly from var. gloriosoides and can be divided into two main groups, i.e. type II (Koshiki-type) and type III (Nagasaki- and Kôchi-types), which differ each other mainly in the feature of leaves and stigmas, and in growing in isolated regions. They may be distinguished taxonomically and may be placed in varietal ranks respectively, as like as the Formosa-type including the Central Chinese group.

Now, the problem is that to wchich type L. speciosum Thunberg belongs. To make clear this point, Thunberg's descriptions $(1784,1811)$ are very obscure, though "acuta" in the tip of leaves is prevalent in the Koshiki-type. The type specimen is preserved in Thunberg's Herbarium in Uppsala and we could see the photograph of it, through the courtesy of Dr. Maekawa and Dr. Hylander. It is the upper part of a plant with five flowers, in which anthers and stigmata are almost destroyed by insects. Judging from the following points, i.e. the shape of leaves, less impressions of the nerves, and marginal undulation being almost absent, we identify the

\footnotetext{
* Contribution No. 14, from the Horticultural Division, Kyushu Agricultural Experiment Station. ** Hort. Div., Kyushu Agr. Exp. Sta.（九州農業試験場園芸部）
} 
type specimen as the plant of Koshiki-type, and venture to apply the name speciosum to the Koshiki-type.

Furthermore, if many plates of $L$. speciosum so far published are examined concerning the shape of stigmata, it is found that the stigmata in the plate in "Kadan Jikinshô" (1694) is truncate, but the figure is too imperfect to be identified, while many plates by Kaempfer in Icones Selectae Plantarum (1791), in "Honzô Zufu" (1828), by Siebold and Zuccarini (1838), as well as in "Yûyô Shokubutsu Zusetsu" (1891) show the Koshiki-type, judging from the shape of stigmata. Accordingly, almost all clones of $L$. speciosum which were grown in Japan at that time, may have been of the Koshiki-type, however, L. speciosum, whose flowers bloom early and are paler in shade, is described in "Senka Oden" (1847) and it may probably belong to the Kôchi-type. All the plates of L. speciosum under the following names are judged to be the Koshiki-type, from the shape of stigmata, Kaempferi, tametomo (Siebold and Zuccarini 1836), lancifolium roseum and album (Paxton 1838, 1841), Kaempferi (Regel 1868), verum (Elwes 1880), Kraetzeri (Grove 1911) as well as rubrum, melpomene, album, Kraetzeri (Yokohama Nursery Co.). Therefore, all the clones which were grown in Europe at that time, may possibly have been of Koshiki-origin, except var. gloriosoides. These variants should be regarded as the forms of the Koshiki-type.

In the classification of forms, only rare characteristics should be adopted in order to establish the whole scheme of variation. For this purpose, we will consult Wilson's classification, which has been regarded as the best work. It classifies the forms as follows : f. rubrum Hort. (Masters); f. melpomene Hort. (Elwes); f. roseum Hort. (Masters); f. punctatum Courtois; f. album Masters; f. Kraetzeri Duchartre; var. tametomeo Sieb. et Zucc.; f. album.novum Hort. (Mallet); f. magnificum Hort. ; var. gloriosoides Baker. To the white-flowered form, the rank of the form (f. vestale) should be rather applied than var. tametomo. The f. Kraetzeri has been distinguished as a peculiar form having orange pollen from other white-flowered forms, but the pollen of the flowers in Grove's plate (1911) is proved to the orange-brown. The pollen of this shade is rather prevalent, and so f. Kraetzeri should not be distinguished from usual white form (f. vestale). The f. rubrum is not given to especially dark-flowered form and its shade of flowers is usual. The f. melpomene is the horticultural variety bred by Hovey through hybridization, and in it no peculiar characteristics can be recognized. Moreover, horticultural varieties should be neglected when we classify botanically, unless they have peculiar characteristics. As f. magnificum is of Koshiki-origin, it ought to be included into speciosum proper.

Thus, we have classified L. speciosum into 3 varieties and 14 forms, including 1 new variety and 9 new forms, as follows:

Lilium speciosum Thunberg in Trans. Linn. Soc., II, 332 (1794), in Mém. Acad. Sci. St. Petersburg, III, 206 (1811). Paxton, Mag. Bot. V. 1, t. (1838). Franchet and Savatier, Enum. Pl. Jap., II, 67 (1879). Elwes, Monog. Lilium, t. 13 (1880). Matsu- 
mura, Ind. Pl. Jap., II, pt. 1, 205 (1905). Grove, Lilies, 69 (1911). Tilton in Bailey, Stand. Cycl. Hort, IV. 1870, fig. 2162 (1916). Wilson, Lilies E. Asia, 75 (1925). Woodcock and Stearn, Lilies World, 334 (1949).

I. Lilium speciosum var. speciosum (ut L. speciosum speciosum).

L. speciosum Thunberg in Trans. Linn. Soc., II, 332 (1794), in Mém. Acad. Sci. St. Petersburg, III. 206 (1811). Paxton, Mag. Bot., V, 1, t. (1838). Elwes, Monog. Lilium, t. 13 (1880). Grove, Lilies. 69 (1911).-'L. superbum L.' Thunberg, Fl. Jap., 134 (1784).-Konokko Juri Banks, Icon. Kaempfer, t. 47 (1791).-Kanoko Juri Iwasaki, Hônzo Zufu, XLVIII (1828)._-“L. lancifolium Hort. Mussche apud Guill Arch. Bot.. 271 (1833)."-L. speciosum $\alpha$ Kaempferi Siebold et Zuccarini, F1. Jap., I, 31, t. 12 (1836)-L. speciosum lancifolium Hort. Neumann in Rev. Hort., V, 494 t. (1844).-L. speciosum var. rubrum Lemair in Fl. des Serr. III, tt. 276-277 (1847).-L. speciosum speciosum Masters in Gard. Chron., 1872, 1522 (1872).-L. speciosum rubrum Masters 1. c.-L. speciosum var. rubrum Masters ex Baker in Jour. Roy. Hort. Soc. IV, 42 (1873).-L. speciosum verum Elwes, Monog. Lilium, t. 13 (1880).-L. speciosum atrosanguineum Hort ex Elwes 1.c. pro syn.-L. speciosum rubrum multiflorum Hort. Rozen and Son ex Elwes 1.c. pro syn.-Kanoko Yuri Tanaka \& Ono, Yûyô Shokubutsu t. 946 (1891).-Aka-kanoko Yokohama Nursery Co. "Yuri Kasen" (Selected Garden Lilies) (1899).-L. speciosum Schrymakersi Hort. Krelage in Jour. Roy. Hort. Soc., XXVI, 363 (1901).-L. speciosum magnificum Hort. Wallace in Jour. Roy. Hort. Soc., XXV, lcxxi (1904), Fox in Addisonia VII, 55, t. 252 (1922).-L. speciosum var. purpuratum Hort. Tilton 1.c.-L. speciosum var. macranthum Hort. Tilton 1.c.-L. speciosum f. magnificum Wilson, Lilies E. Asia, 77 (1925).

Bulb rather flattened globose to globose, brownish yellow (intermediate between 19 and $17 / \mathrm{b}$ )* tinged with pink $\left(1^{\prime \prime} \mathrm{d}\right.$ ) on the summit, pink $\left(1^{\prime \prime} \mathrm{b}\right)$, dull rose $\left(1^{\prime}\right)$, or reddish purple $(1 \mathrm{k})$, sometimes brownish yellow, $5-12 \mathrm{~cm}$. in diameter (usually $7-9 \mathrm{~cm}$ ); scales thick, rather tightly imbricated, lanceolate-ovate, $5.5-7 \mathrm{~cm}$. long, $2.2-2.7 \mathrm{~cm}$. wide, acute or acuminate, incurved. Stem 0.5-0.9 m. long, erect, terete, rigid, glabrous, green $\left(27^{\prime \prime}\right.$ or $\left.31 \mathrm{k}\right)$, or light brown $\left(9^{\prime \prime \prime} \mathrm{i}\right)$, or purplish brown $\left(71^{\prime \prime} \mathrm{m}\right.$ or $\left.1^{\prime \prime \prime} \mathrm{m}\right)$. Leaves scattered, phyllotaxis $2 / 5$ or $3 / 8,1 / 2$ on the upper part of stem when young, petioled, glabrous, yellowish green (31k), rather leathery, lanceolate to oblong-ovate, 11 to $17 \mathrm{~cm}$. long, 3 to $5 \mathrm{~cm}$. wide, $0.4-0.5 \mathrm{~mm}$. thick, acute, rarely somewhat attenuate, base rounded or broad-cuneate, distinctly 5-7-nerved, slightly impressed along nerves; petiole $0.5-2 \mathrm{~cm}$. long, adpressed to stem. Flowers rose-carmine (somewhat deeper than 71b) to rose-pink (71d), whitemargined, or faded gradually towards the margin, sometimes blotched only in the middle, spotted with dark crimson (intermediate between $71 \mathrm{k}$ and $71 \mathrm{i}$ ) to rose (71b), usually sub-pendulous, sometimes sub-erect, lateral or pendulous, fragrant, 1-30 (usually 3-10), racemose; pedicels rigid, spreading and ascending-spreading, $9-11 \mathrm{~cm}$. long, $0.3-0.4 \mathrm{~cm}$. in diameter, upper the shorter, bracts and bracteoles foliaceous; perianth-segments refiexed, slightly waved in the margin, lanceolate to ovate, $6.5-10 \mathrm{~cm}$. long, $2.5-4 \mathrm{~cm}$. (inner segments), $2-2.5 \mathrm{~cm}$. (outer segments) wide, apiculate, lower face with abundant, raised, fleshy colored papillae, without keel, nectariferous furrow light green (31i), yellowish green (27i), greenish yellow $\left(25^{\prime /} \mathrm{b}\right)$, or light yellow (25f), glabrous; stamens shorter than the perianth, widely divergent, filaments subulate, glabrous, anthers $2-2.5 \mathrm{~cm}$ long; pollen chocolate-brown (3k, 5k) or organe-brown (7i); pistil slightly overtopping stamens, ovary $15-25 \mathrm{~mm}$. long, $3.5-4.5 \mathrm{~mm}$. in diameter, style curving slightly thickened upward, stigma capitate. Blossoms in late July to early August. Fruit obovoid-cylindrical, 5-7 cm. long, obtusely

\footnotetext{
* Color symbols from "Ridgway's Color Standards and Color Nomenclature".
} 
angled, summit umbillicate.

Nom. Jap.: Shima-Kanokoyuri (nom. hort., etymologia Shima-insula, Kanokoyuri-Lilium cum tepalis punctatis).

Hab.: Kyûshû: Kagoshima Pref.-on the western part of mainland. (a part) and on the Islands of Koshiki (abundant). Kumamoto Pref.-on the Islands of Amakusa (rare). Fukuoka Pref.-Munakata and Onga Districts (a part).

1. Lilium speciosum var. speciosum $f$. coccineum $S$. Abe et Tamura f. nov.

Flowers crimson (somewhat paler than 71), margined with white, spotted with brodeaux $(71 \mathrm{k})$ to dark crimson.-Flores coccinei, argento-marginati, maculis atrococcineis punctati.

2. Lilium speciosum var. speciosum f. roseum Masters, in Gard. Chron., 1872, 1522 (1872) (ut L. speciosum roseum).

L. speciosum var. roseum Masters ex Baker in Jour. Roy. Hort. Soc. IV, 42 (1873).- 'L. speciosum punctatum' Elwes, 1.c.

Flowers pink (71f), spotted various shades.

3. Lilium speciosum var. speciosum f. album Masters in Gard. Chron. 1872, 1522 (1872) (ut L. speciosum album).

Ryukyu Yuri Iwasaki, Honzô Zufu XLVIII (1828)--L. speciosum var. album Masters ex Baker in Jour. Roy. Hort. Soc., IV, 42 (1873).

Flowers faint pink. not spotted.

4. Lilium speciosum var. speciosum f. vestale Masters, in Gard. Chron., 1872, 1522 (ui L. speciosum vestale). Elws, Monog. Lilium t. 13 (1880).

“L. Broussartii Morren apud Mons in Hort. Belg., I, 371, t. 23 (1834)".-L. speciosum $\beta$ tametomo Sieb. et Zucc. in Fl. Jap. I, 31, t. 13 (1836).-L. speciosum var. Album, Paxton, Mag. Bot VIII, 127 t. (1841).-L. eximium Hort. ex Kunth, Enum. Pl. IV, 259 (1843) non Courtois, pro syn.-L. speciosum f. Kraetzeri Duchartre ex Baker in Jour. Linn. Soc. XIV, 234 (1875).-Shiro-Kanoko Yokohama Nursery Co., “Yuri Kasen" (Selected Garden Lilies) (1899).-L. speciosum Album Kraetzeri Hort. Krelage in Jour. Roy. Hort. Soc. XXVI, 363 (1901).-L. speciosum roseum album P. Barr in Gard. Chron. ser. 3, XXXII, 129 (1902).-L. speciosum var. Kraetzeri Hort. ex Grove, Lilies, t. 3 (1911).

Flowers pure white, not spotted.

5. Lilium speciosum var. speciosum f. album-novum Mallet in Gard. Chron., ser. 3, XXX, 24 (1901).

L. speciosum punctatum album P. Barr in Gard. Chron, ser. 3, XXXII, 129 (1902). -'L. speciosum var. Kraetzeri', Yokohama Nursery Co., Illus. Gard. Pl. Jap., II, 5, Fig. 205 (1914).-L. speciosum var. album-novum Woodcock \& Stearn, Lilies World, 339 (1949).

Flowers white, not spotted, pollen yellow (13-15).

6. Lilium speciosum var. speciosum f. concolor S. Abe et Tamura f. nov. 'L. speciosum Thunb' Lindley in Bot. Reg. XXIII, t. 2000 (1837).

Flowers crimson, colored entirely, leaving narrow white edge, spotted with dark 
crimson.-Flores in toto faciem coccinei, sed angustissime albo-marginati, maculis brunneo-coccineis punctati.

7. Lilium specioum var. speciosum f. radiatum $S$. Abe et Tamura f. nov.

Flowers white, rayed with rose (intermediate between $71 \mathrm{~b}$ and $71 \mathrm{~d}$ ) to rose pink (71 d) stripes, spotted with various shades.-Flores albi, roseo vel dilute roseo-vittatis, maculis coloribus ornati.

8. "Lilium speciosum var. speciosum f. punctatum Courtois in Cat. Agric. Bot. Gand., 1844, 26" (forsan ut L. speciosum f. punctatum).

L. lancifolium roseum Paxton, Mag. Bot., V, 267 t. (1838).-L. lancifolium punctatum Hort. ex Paxton 1.c. pro syn.- “L. speciosum var. punctatum Marnock in Fl. M., 4, 136, t. 44 (1839)".-L. speciosum albiflorum Hooker in Bot. Mag., LXVI, t. 3785 (1840).-L. punctatum Hort. ex Lemaire in Fl. des Serr., III, sub tt. 276-277 (1847).

Flowers white, spotted with pink (71f), pollen yellow.

9. Lilium speciosum var. speciosum f. rubro-punctatum $S$. Abe et Tamura f. nov.

Flowers white, spotted deep rose (71i), pollen brown.-Flores candidi, maculis intense-roseis punctati, pollinibus brunneis.

10. Lilium speciosum var, speciosum f. compactum $S$. Abe et Tamura f. vov.

Stem dwarf, flowers compact.-Planta humilior; flores compacte aggregati.

11. Lillium speciosum var. speciosum f. erectum Walker in Am. Lily Yearbook, 1942, 108.

Flowers suberect to lateral.-Flores suberecti vel lateraliter patet.

The name f. erectum described by Scrase-Dickins (Roy. Hort. Soc. Lily Yearbook, IV $, 127,1935)$ seems to be derived from the erect character in the stem. Hence, we adopt Walker's name in spite of its later publication.

II. Lilium speciosum var. clivorum $\mathrm{S}$. Abe et Tamura var. nov.

'L. speciosum var. gloriosoides Baker' Grove in New Fl. Silva, III, Fig. VII (1930).- 'L. speciosum punctatum', Wallace in Roy. Hort. Soc. Lily Yearbook, IV, 126 (1935).

Bulb flattened globose, scales rather loosely imbricated, $4-6 \mathrm{~cm}$. long, $1.3-2 \mathrm{~cm}$. wide, lanceolate, acuminate. Stem rather slender, 0.9-1.3 m. long, tending from suberect to sub-pendulous, usually nodding at the top. Leaves tending to $1 / 2$-phyllotaxis, subnutant, broad-lanceolate to elliptic-ovate, slightly larger than the type, $12-20 \mathrm{~cm}$. long, 4-6 cm. wide, $0.2-0.3 \mathrm{~mm}$. thick, attenuate, rather dark green $\left(31^{\prime \prime} \mathrm{m}\right)$, strongly impressed along nerves, wavy in the margin. Flowers more lightly colored than the type, faded or margined, sometimes blotched, pendulous; blossoms 2-3 weeks earlier than the type; pedicel rather slender, $11-14 \mathrm{~cm}$. long, $0.25-0.3 \mathrm{~cm}$. diameter; perianth-segments much reflexed, much wavy; stigma subcapitately truncate.

Plant growing in Nagasaki is similar to the plant from Shikoku, but differs in the following characteristics.

Bulb globose, but slightly flattened; scales broad-lanceolate; stem 0.6 to $1 \mathrm{~m}$. long, tending to sub-erect; leaves moderate green $(31 \mathrm{~m})$. Blossoms 2-3 weeks ear- 
lier than the type variety, but later than the plant from Shikoku; pedicels rather rigid, $8-11 \mathrm{~cm}$. long, $0.3-0.4 \mathrm{~cm}$. in diameter.

Folia: phyllotaxis plerumque $1 / 2$, nutantiuscula late lanceolata vel ovatc-elliptica, apice gradatim attenuata, nervis valde impressis, margine repanda. Flores; stigmate subcapitao-truncata, patet praecocciore quam typo.

Nom Jap.: Taki-Yuri (nom. vernacul. in Shikoku. Etymologia Taki-cautes, YuriLilium).

Specimina typica: Tosayama, Kôchi (S. Abe, Typus in Herb. Univ. Tokyo).

Hab.: Shikoku; Kôchi Pref.-on valleys in the Aki, Kami, Takaoka and Tosa District, and Kôchi City. Tokushima Pref.-on valleys in Naka, Myozai and Mima District (a part), and on the Island of Ôshima. Kyûshî; Nagasaki Pref.-on the western coast of Nishisonogi Peninsula, and on the Islands of Matsushima and Kujûku-shima.

1. Lilium speciosum var. clivorum f. metaroseum S. Abe et Tamura f. nov.

Flowers pink, spotted with various shades.-Flores rosacei, maculis coloribus ornati.

2. Lilium speciosum var. clivorum $f$. vittatum $S$. Abe et Tamura $f$. nov.

Flowers white, rayed with rose to rose pink stripes, spotted with various shades. -Flores albi, tepalis medio roseo-vittatis, maculis coloribus ornati.

III. Lilium speciosum var. gloriosoides Baker in Gard. Chron., n. s. XIV, 198 (1880). Wright in Jour. Linn. Soc. XXXXI, 134 (1903). J. H. Veitch, Hortus Veitchii, 450 (1906). Watson in New Fl. Silva IV, Fig. LXXVI (1931). Wilson, Lilies E. Asia, 77 (1925). Woodcock \& Stearn, Lilies World, 340 (1949).

'L. speciosum Kaempferi Sieb. et Zucc.' Hance in Jour. Bot., XII, 262 (1874).'L. speciosum Thunb.' Franchet in Pl. David., I, 307 (1884).--L. lancifolium var. gloriosoides Bretschneider, Hist. European Bot. Disc. Chin., 742 (1898).-L. lancifolium formosanum J. H. Veitch, 1.c. 82.-L. auratum gloriosoides J. H. Veitch, 1.c. 83.-L. Konishii Hayata in Jour. Coll. Sci. Tokyo, XXX, art. 1, 364 (1911).-L. Kanahirai Hayata, Icon. Pl. Formosan., II, 146 (1912).

Bulb yellow, flattened globose, scale lanceolate-ovate, $2.2-2.5 \mathrm{~cm}$ wide. Leaves lanceolate to oblong-ovate, $12-20 \mathrm{~cm}$. long, $0.45-0.5 \mathrm{~mm}$. thick, scarcely impressed along veins. Flowers white, largely blotched with crimson to the center or spotted crimson to dark crimson; perianth segments much reflexed, wavy, raised fleshy papillae numerous, nectariferous furrow relatively long, green (29 k); stigma subcapitately truncate; sub-constrict; blossoms later than the type.

Nom. Jap.: Taiwan-Kanokoyuri.

Hab.: East central China ; Lushan mountains, Kiangsi Province. Formosa ; Sekitei, Heirimbi and Dandaigai, Taihoku Province.

1. Lilium speciosum var. gloriosoides f. sanguineo-punctatum S. Abe et Tamura f. nov.

Flowers white, spotted with crimson, pollen brown.-Flores albi, maculis sanguineis punctati, pollinibus brunneis.

(To be continued) 